\author{
Renata Nesterowicz \\ Uniwersytet Rzeszowski, Polska - University of Rzeszów, Poland \\ JOANNA NAKONIECZNY \\ Politechnika Rzeszowska, Polska - Rzeszów University of Technology, Poland
}

\title{
Ocena wyników działalności wybranych spółek budowlanych notowanych na GPW w świetle ogólnej sytuacji branży
}

\section{Assessment of the performance of selected construction companies listed on the Warsaw Stock Exchange in the light of the overall situation of the industry}

\begin{abstract}
Streszczenie: Sektor budownictwa charakteryzuje się dużą zmiennością sytuacji finansowej funkcjonujących w nim podmiotów (generalnych wykonawców, podwykonawców, producentów materiałów oraz hurtowników). Wpływa to na sposób dokonywania oceny całej branży przez instytucje bankowe i ubezpieczeniowe zapewniające przedsiębiorstwom budowlanym dostęp do gwarancji i zewnętrznego finansowania. Trudny rynek, nawet w czasie hossy, zmienna koniunktura, wielostopniowa realizacja kontraktów powodują, że sektor budowlany ma problemy z utrzymaniem płynności finansowej oraz obsługą zadłużenia. Przeprowadzone w niniejszym artykule rozważania pozwalają stwierdzić, że ostatnie lata nie były łatwe dla branży budowlanej, na co złożyło się wiele czynników. Realizacja nierentownych kontraktów infrastrukturalnych, trudności w dialogu z inwestorem środków publicznych, a także ograniczona liczba przetargów niekorzystnie wpłynęły na wyniki finansowe spółek tego sektora. Analizowane spółki budowlane z grupy notowanych na Giełdzie Papierów Wartościowych utrzymały w badanym okresie dobrą kondycję finansową. Głównym celem niniejszego opracowania jest ocena wyników pięciu przedsiębiorstw branży budowlanej notowanych na GPW na podstawie wybranych informacji finansowych za lata 2014-2019. Dane te zostały przeanalizowane pod kątem dynamiki oraz średniego tempa wzrostu z wykorzystaniem metody ṛ, której istota wynika $\mathrm{z}$ tego, że tylko początkowy i końcowy wyraz szeregu chronologicznego decyduje o wartości liczbowej średniego tempa wzrostu. Faktyczny szereg chronologiczny można traktować jako „postęp geometryczny o zmiennym ilorazie”. Opracowanie ma charakter opisowo-empiryczny.
\end{abstract}

Abstract: The construction sector is characterised by high volatility in the financial situation of
the entities operating in it (general contractors, subcontractors, material producers and whole-
salers). This affects how the industry is assessed by banking and insurance institutions that provide
construction companies with access to guarantees and external financing. A difficult market, even
during a bull market, volatile economic situation, multi-stage execution of contracts mean that the
construction sector has problems with maintaining financial liquidity and debt service. The conside- 
rations carried out allow to conclude that the recent years have not been easy for the construction industry, which was due to many factors. The implementation of unprofitable infrastructure contracts, difficulties in dialogue with an investor of public funds, as well as a limited number of tenders adversely affected the financial results of companies in this sector. The analysed construction companies from the group listed on the Warsaw Stock Exchange maintained their good financial condition in the analysed period. The main purpose of this study is to evaluate the performance of five companies in the construction industry listed on the WSE on the basis of selected financial information for 2014-2019. These data will be analysed in terms of dynamics and average growth rate using the $\bar{r}$, method, the essence of which results from the fact that only the initial and final expression of the chronological series determines the numerical value of the average growth rate. The actual chronological series can be thought of as "a geometric progression with a variable quotient". The study is descriptive and empirical.

Słowa kluczowe: analiza; budownictwo; gospodarka; przedsiębiorstwa

Keywords: analysis; construction; economy; enterprises

Otrzymano: 24 października 2021

Received: 24 October 2021

Zaakceptowano: 5 grudnia 2021

Accepted: 5 December 2021

\section{Sugerowana cytacja/Suggested citation:}

Nesterowicz, R., Nakonieczny, J. (2021). Ocena wyników działalności wybranych spółek budowlanych notowanych na GPW w świetle ogólnej sytuacji branży. Przedsiębiorczość - Edukacja [Entrepreneurship - Education], 17(2), 26-36. https://doi.org/10.24917/20833296.172.2

\section{Wstęp}

Gospodarka rynkowa charakteryzuje się coraz większą konkurencją i złożonością procesów gospodarczych. Uzyskiwanie przewagi konkurencyjnej wymusza zmiany w systemie podejmowania decyzji, szybszego przekazywania kierownictwu pewniejszych i lepszych informacji (Skowronek-Mielczarek, Leszczyński, 2008). Niewątpliwie takich informacji dostarcza analiza, przeprowadzona zgodnie ze sztuką ekonomii, a opierająca się na rzetelnie sporządzonej sprawozdawczości finansowej.

Podmioty gospodarcze - przedsiębiorstwa - nigdy nie istniały i nigdy nie będą istnieć dla samego trwania. Musiały one spełniać liczne oczekiwania, które były formułowane zarówno przez właścicieli, kontrahentów, jak i przez pracowników. Dlatego też aby osiągnąć wszystkie cele, przedsiębiorstwo formułuje strategie działania, które obejmują najważniejszy cel działania, jakim jest zwiększanie wartości działalności gospodarczej. Wykorzystuje do tego informacje o otoczeniu firmy, a także zawarte w sprawozdaniach finansowych (Zabrowarny, 2004).

Cechą charakterystyczną branży budowlanej jest jej wyjątkowa wrażliwość na wahania koniunktury oraz zmiany zachodzące w otoczeniu makroekonomicznym i polityczno-prawnym. Konsekwencją specyfiki sektora budownictwa jest duża zmienność sytuacji finansowej funkcjonujących w nim podmiotów (generalnych wykonawców, podwykonawców, producentów materiałów oraz hurtowników). Wpływa to na sposób dokonywania oceny całej branży przez instytucje bankowe i ubezpieczeniowe zapewniające przedsiębiorstwom budowlanym dostęp do gwarancji i zewnętrznego finansowania. 
Trudny rynek, nawet w czasie hossy, zmienna koniunktura, wielostopniowa realizacja kontraktów powodują, że sektor budowlany ma problemy z utrzymaniem płynności finansowej oraz obsługą zadłużenia.

Według danych publikowanych przez Krajowy Rejestr Długów (dane z września 2021), budownictwo, zaraz po handlu, to jedna $z$ najbardziej obciążonych długami branż w polskiej gospodarce. Łączne zadłużenie firm z sektora budowlanego wynosi już blisko 1,8 mld zł, z czego połowa tej kwoty to długi jednoosobowych działalności gospodarczych. Poza tym należy zaznaczyć, że sytuacja firm budowlanych wpływa również na inne sektory gospodarki. Połowę swojego zadłużenia firmy budowlane są winne instytucjom finansowym - $900 \mathrm{mln}$ zł. Następnie wymienia się handel oraz firmy zajmujące się wynajmem i sprzedażą maszyn (37 mln zł). Wzajemne długi branży (czyli zobowiązania wobec innych firm budowlanych) wyniosły $158 \mathrm{mln}$ zł (MerXu, 2021).

Głównym celem niniejszego opracowania jest ocena wyników pięciu przedsiębiorstw branży budowlanej notowanych na GPW na podstawie wybranych informacji finansowych za lata 2014-2019. Dane te zostaną przeanalizowane pod kątem dynamiki oraz średniego tempa wzrostu $\mathrm{z}$ wykorzystaniem metody $\bigotimes$, której istota wynika $\mathrm{z}$ tego, że tylko początkowy i końcowy wyraz szeregu chronologicznego decyduje o wartości liczbowej średniego tempa wzrostu. Faktyczny szereg chronologiczny można traktować jako „postęp geometryczny o zmiennym ilorazie” (Timofiejuk, 1973). Opracowanie ma charakter opisowo-empiryczny.

\section{Zmiany koniunktury na rynku budowlanym w ostatnich latach}

W ostatnim czasie koniunktura na rynku budowlanym zmieniała się pod wpływem wielu czynników, z których można wymienić m.in.:

- kryzysowe dla branży lata 2012-2013 zakończone bankructwem setek firm budowlanych, do czego przyczyniła się w dużej mierze realizacja nierentownych kontraktów infrastrukturalnych na EURO 2012,

- okres umiarkowanej poprawy koniunktury na przełomie 2014/2015 r. wynikającej z finalizacji wielu projektów inwestycyjnych na zakończenie perspektywy finansowej Unii Europejskiej na lata 2007-2014,

- całkowity zastój w inwestycjach w 2016 r. wskutek opieszałości w wydatkowaniu funduszy unijnych z nowej perspektywy budżetowej na lata 2014-2020,

- pierwsze oznaki ożywienia na przełomie 2016/2017 r., kiedy ruszyły wyczekiwane od wielu miesięcy przetargi na realizację projektów infrastrukturalnych współfinansowanych ze środków UE.

Według przeprowadzonych przez Euler Hermes badań, liczba niewypłacalnych firm budowlanych w poszczególnych latach kształtowała się następująco: 2010 r. - 58, 2011 r. 75, 2012 r. - 124, 2013 r. - 133, 2014 r.- 98, 2015 r. - 66, 2016 r. - 71, 2017 r. - 73, 2018 r. 89 firm (Deloitte, 2019).

Pierwsze półrocze 2018 r. upłynęło pod znakiem bardzo dobrej koniunktury na rynku budowlanym. Przyczyniły się do tego: sprzyjająca rozwojowi koniunktura na rynku budownictwa mieszkaniowego, biurowego i magazynowego oraz wyraźny wzrost nakładów inwestycyjnych przedsiębiorstw na budynki i budowle, a także trwający od końca 2017 r. rozkwit inwestycji samorządowych. 
Jednak sytuacja bardzo szybko zaczęła się pogarszać. Jak podaje Dariusz Blocher, prezes BUDIMEX S.A. (Blocher, 2018), kondycja finansowa branży budowlanej zmieniła się niekorzystnie zarówno przez istotny wzrost cen materiałów, rozwiązania takie jak odwrócony VAT, przeregulowanie rynku, niedobór ludzi do realizacji kontraktów oraz brak realnej waloryzacji kosztów w umowach $\mathrm{z}$ inwestorami publicznymi.

Rządowe rozwiązania nakierowane na uszczelnienie systemu podatkowego przyczyniły się do pogorszenia bieżącej płynności firm budowlanych. Od początku 2017 r. w rozliczeniach wykonawców z podwykonawcami usług budowlanych obowiązuje mechanizm tzw. odwróconego VAT (ang. reverse charge), w którym to nabywca usług, a nie ich wykonawca jest podmiotem zobowiązanym do rozliczenia podatku VAT. W praktyce oznacza to, że podwykonawcy wystawiają faktury bez VAT (Nykiel, Sęk, 2018). Jednocześnie płacą za nabywane towary i niektóre usługi z VAT oraz czekają na jego zwrot z urzędu skarbowego. Według informacji płynących z rynku budowlanego, zdarzały się przypadki, gdy okres zwrotu podatku VAT przekraczał znacząco 120 dni. Oprócz nasilenia zatorów płatniczych, mechanizm odwróconego VAT doprowadził do zwiększenia kosztów finansowania bankowego w celu pokrycia luki w rozliczeniach tego podatku oraz do ponad 20-procentowego wzrostu cen usług podwykonawczych. W sytuacji jednoczesnego utrzymywania zasady rozliczenia za szereg usług budowlanych poprzez odwrócony VAT branża budowlana obawiała się wprowadzenia mechanizmu podzielonej płatności (MPP) (ang. split payment), który zaczął obowiązywać od 1 lipca 2018 r (Kieszkowski, 2018). Mechanizm ten oznacza, że jeżeli nabywca decyduje się na formę podzielonej płatności, wówczas zapłata za towar lub usługę jest dzielona na dwie części: kwotę netto, która wpływa na rachunek sprzedawcy, oraz podatek VAT, który trafia na specjalnie wydzielone konto bankowe przeznaczone wyłącznie do regulacji zobowiązań podatkowym z fiskusem i rozliczeń kwoty VAT z kontrahentami. Co istotne, bez decyzji naczelnika urzędu skarbowego firma nie może swobodnie dysponować kwotą zgromadzoną na rachunku VAT. Wbrew pierwotnym sygnałom wdrożenie MPP nie spowodowało wycofania się Ministerstwa Finansów z mechanizmu odwróconej płatności, a pomimo całego systemu zachęt przygotowanych przez fiskusa (m.in. brak sankcji w VAT, zwolnienie z odpowiedzialności solidarnej, przyspieszony zwrot VAT) zachodzi uzasadniona obawa, że wdrożenie MPP doprowadzi do dalszego pogorszenia kondycji finansowej podmiotów z sektora budownictwa, wpłynie negatywnie na zatory płatnicze i zwiększy zapotrzebowanie na zewnętrzne finansowanie. Może też niepokoić, że MPP będzie stosowany przez zamawiających jako podstawowa forma płatności za realizację zamówień publicznych. Nadal niewyjaśniona pozostaje także kwestia zastosowania MPP w rozliczeniach inwestorów publicznych z konsorcjami realizującymi usługi budowlane. Zwyczajowo płatność za wykonaną umowę trafia na specjalny rachunek powierniczy, a lider rozlicza się z niej ze swoimi konsorcjantami, jednak w myśl obowiązujących przepisów rachunki powiernicze nie mogą być wykorzystywanie do płatności podzielonych.

Nadmienić przy tym należy, że pandemia COVID-19 miała ogromny wpływ na gospodarkę w roku obrotowym 2020. Sektor budowlany został dotknięty skutkami wywołanymi przez pandemię $\mathrm{w}$ mniejszym stopniu niż inne branże, nie ominęło go to jednak całkowicie. Pandemia wywarła krótko- i długoterminowy wpływ na rozwój sektora w nadchodzących latach, gdyż wzrost wydatków publicznych wymagany do złagodzenia kryzysu wpłynie na wysokość zadłużenia poszczególnych krajów. Może to zagrozić stabilności finansów publicznych w niektórych państwach, a w konsekwencji inwestycjom infrastrukturalnym, od których zależy kondycja branży budowlanej (Krasoń, 2021). 
Ocena wyników ekonomicznych wybranych spółek branży budowlanej notowanych na GPW

Ocena wyników ekonomicznych wybranych spółek branży budowlanej zostanie przeprowadzona na przykładzie pięciu firm notowanych na Giełdzie Papierów Wartościowych. W pierwszej kolejności zostaną przeanalizowane całkowite przychody tych spółek, co zostało przedstawione w tabeli 1.

Tabela 1. Przychody całkowite wybranych spółek branży budowlanej za lata 2014-2019 (w tys. zł)

\begin{tabular}{|c|c|c|c|c|c|c|c|c|}
\hline Wyszcz & gólnienie & 2014 & 2015 & 2016 & 2017 & 2018 & 2019 & $\begin{array}{c}\overline{\mathbf{r}} \\
\text { średnie }\end{array}$ \\
\hline Budimex & $P^{\star}(w$ tys. $\left.z\}\right)$ & 4949939 & 5133994 & 5572290 & 6369 & 7387137 & 7569663 & 8,7 \\
\hline Group & $\mathrm{D}^{* \star}(\mathrm{w} \%)$ & - & 3,7 & 8,6 & 14,3 & 16,0 & 2,5 & . \\
\hline Strabag & $\mathrm{P}^{\star}(\mathrm{w}$ tys. $\mathrm{z})$ & 3142849 & 3853846 & 3423635 & 3635775 & 4097061 & 4606091 & 7,5 \\
\hline Group & $\mathrm{D}^{* \star}(\mathrm{w} \%)$ & - & 22,0 & $-11,0$ & 6,2 & 12,7 & 12,4 & - \\
\hline Polimex & $\mathrm{P}^{\star}(\mathrm{w}$ tys. $\mathrm{z})$ & 2102197 & 2548575 & 2668221 & 2421078 & 1636869 & 1589430 & 1,1 \\
\hline Group & $D^{* *}(w \%)$ & - & 21,2 & 4,7 & $-9,3$ & 10,5 & $-5,9$ & - \\
\hline Warbud & $\mathrm{P}^{\star}(\mathrm{w}$ tys. $\mathrm{z} \mathrm{l})$ & 1049886 & \begin{tabular}{|l|l|}
1106860 \\
\end{tabular} & 930435 & 1028076 & 1565275 & 1641026 & 6,0 \\
\hline & $D^{* *}(w \%)$ & - & 5,4 & $-15,9$ & 10,5 & 52,3 & 4,8 & - \\
\hline$\overline{\mathrm{PBG}}$ & $\mathrm{P}^{\star}(\mathrm{w}$ tys. $\mathrm{zl})$ & 1530248 & 1798815 & 1987014 & 1869093 & 1318157 & 1284897 & 2,5 \\
\hline Group & $\mathrm{D}^{\star \star}(\mathrm{w} \%)$ & - & 17,6 & 10,5 & $-5,9$ & $-29,5$ & $-2,6$ & - \\
\hline
\end{tabular}

$\mathrm{P}^{*}$ - przychody całkowite, $\mathrm{D}^{* *}$ - dynamika

Źródło: Opracowanie własne na podstawie Deloitte (2019)

Analiza przychodów z działalności wybranych spółek notowanych na GPW za lata 2014-2019, pozwala zauważyć, że tylko spółka Budimex Group odnotowała stabilny wzrost przychodów. Wykorzystując w badaniu metodę ṛ średniego tempa wzrostu, dla spółki tej ustalono, że przeciętny wzrost przychodów na przestrzeni badanych lat wyniósł $8,7 \%$. Pozostałe spółki wykazały duże wahania w dynamice: zarówno dodatnie, jak i ujemne. W rezultacie dało to uśredniony wynik dodatni średniego tempa wzrostu dla: Strabag Group - 7,5\%, Polimex Mostostal Group - 1,1\%, Warbud S.A. - 6,0\%, PBG Group - $2,5 \%$ wzrostów.

Następnie analizie poddany został wynik ze sprzedaży, co przedstawiono w tabeli 2.

Poddając analizie wynik uzyskany ze sprzedaży rozumiany jako różnica pomiędzy przychodami operacyjnymi a kosztami własnymi sprzedaży, widać dosyć duże wahania $\mathrm{w}$ dynamice. Spowodowane jest to znaczącymi różnicami w wyniku ze sprzedaży w poszczególnych latach. W 2014 r. spółka Polimex Mostostal Group odnotowała sporą stratę w kwocie (-201 623 tys. zł), natomiast Strabag Group w 2018 r. wykazała stratę (-74 005 tys. zł), zaś rok później -31947 tys. zł. Pozostałe spółki w badanych latach miały wyniki dodatnie. Konsekwencją dużych wahań w dynamice było zróżnicowane średnie tempo wzrostu zysku ze sprzedaży, które wyniosło dla: Budimex Group - 13,7\%, PBG Group 14,9. Pozostałe spółki wykazały ujemne średnie tempo wzrostu. 
Tabela 2. Wynik ze sprzedaży wybranych spółek branży budowlanej za lata 2014-2019 (w tys. zł)

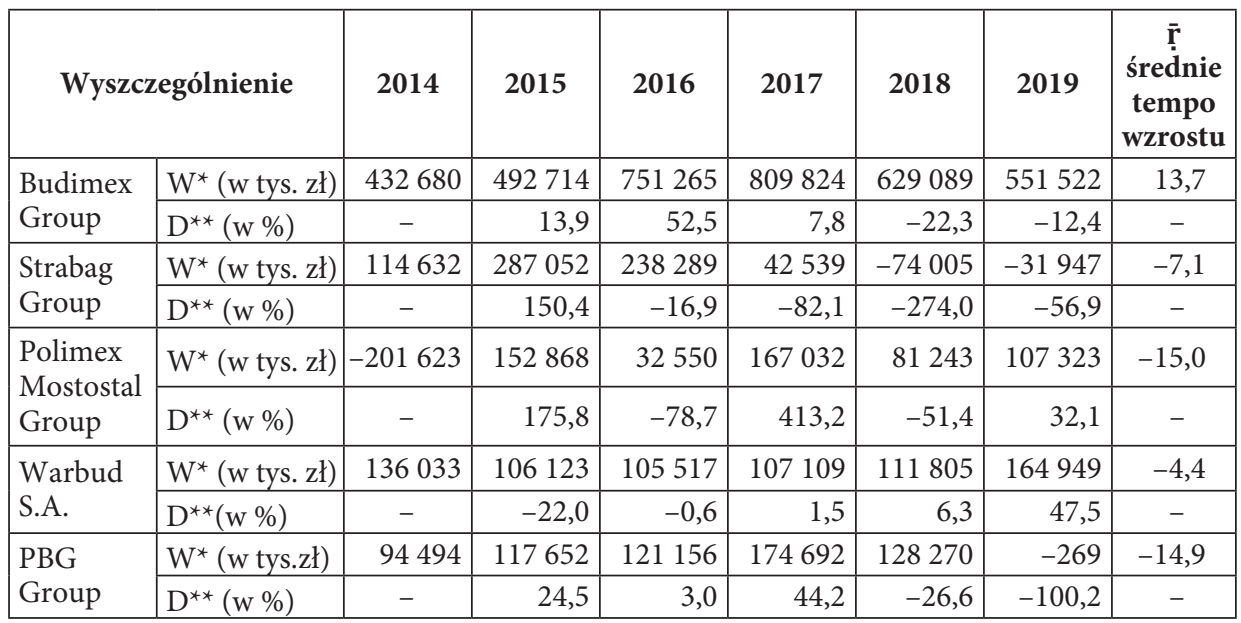

$\mathrm{W}^{\star}$ - wynik ze sprzedaży, $\mathrm{D}^{* *}$ - dynamika

Źródło: Opracowanie własne na podstawie Deloitte (2019)

Podczas badań przeanalizowano również wynik finansowy netto jako jeden ze wskaźników odzwierciedlających kondycję badanych spółek. Uzyskane wyniki przedstawiono w tabeli 3.

Tabela 3. Wynik finansowy netto wybranych spółek branży budowlanej za lata 2014-2019 (w tys. zł)

\begin{tabular}{|c|c|c|c|c|c|c|c|c|}
\hline \multicolumn{2}{|c|}{ Wyszczególnienie } & \multirow{2}{*}{$\begin{array}{c}2014 \\
193938 \\
\end{array}$} & \multirow{2}{*}{\begin{tabular}{c|}
2015 \\
236520 \\
\end{tabular}} & \multirow{2}{*}{$\begin{array}{c}2016 \\
410476\end{array}$} & \multirow{2}{*}{\begin{tabular}{c|}
2017 \\
464594 \\
\end{tabular}} & \multirow{2}{*}{\begin{tabular}{c|}
2018 \\
305484 \\
\end{tabular}} & \multirow{2}{*}{$\begin{array}{c}2019 \\
228851 \\
\end{array}$} & \multirow{2}{*}{\begin{tabular}{|c|c}
$\begin{array}{c}\overline{\mathbf{r}} \\
\text { średnie } \\
\text { tempo } \\
\text { wzrostu }\end{array}$ \\
18,2 \\
\end{tabular}} \\
\hline & Wfn* (w tys. zł) & & & & & & & \\
\hline Group & $\mathrm{D}^{* *}(\mathrm{w} \%)$ & - & 22,0 & 73,6 & 13,2 & $-34,2$ & 74,9 & - \\
\hline \multirow{2}{*}{$\begin{array}{l}\text { Strabag } \\
\text { Group }\end{array}$} & Wfn* (w tys. zł) & 148981 & 177987 & 230725 & 37112 & 37090 & 166264 & 3,4 \\
\hline & $D^{* *}(\mathrm{w}$ & - & 19,0 & 29,5 & $-83,9$ & $-0,1$ & 448,3 & - \\
\hline \multirow{2}{*}{$\begin{array}{l}\text { Polimex } \\
\text { Mostostal } \\
\text { Group }\end{array}$} & s. zł) & -153226 & 68975 & -60706 & -137044 & 16168 & 50654 & $-15,0$ \\
\hline & $\mathrm{D}^{\star *}(\mathrm{w} \%)$ & - & 145,0 & $-1188,0$ & 225,8 & 111,8 & 313 , & - \\
\hline \multirow{2}{*}{$\begin{array}{l}\text { Warbud } \\
\text { S.A. }\end{array}$} & Wfn* (w tys. zl) & 48416 & 35728 & 35129 & 30127 & 15543 & 37292 & $-14,8$ \\
\hline & $\mathrm{D}^{\star \star}(\mathrm{w} \%)$ & - & $-26,0$ & $-1,7$ & $-14,2$ & $-48,4$ & 239,9 & - \\
\hline \multirow{2}{*}{$\begin{array}{l}\text { PBG } \\
\text { Group }\end{array}$} & $\mathrm{Wfn}^{*}(\mathrm{w}$ tys. $\mathrm{zl})$ & -80799 & -201104 & 788747 & 94221 & -48853 & -487369 & $-15,0$ \\
\hline & $\mathrm{D}^{* *}(\mathrm{w} \%)$ & - & $-149,0$ & 492,2 & $-88,1$ & 48,2 & 997,6 & - \\
\hline
\end{tabular}

Wfn ${ }^{*}$ - wynik ze sprzedaży, $\mathrm{D}^{* *}$ - dynamika

Źródło: Opracowanie własne na podstawie Deloitte (2019)

Jak wynika z danych przedstawionych w powyższej tabeli, najlepszy wynik w badanych latach wykazały spółki Budimex Group i Strabag Group. Z kolei spółka Warbud 
S.A. utrzymywała wynik dodatni charakteryzujący się jednak dynamiką ujemną. Najgorzej plasowała się spółka PBG Group, która zamknęła cztery lata działalności stratami. W rezultacie obserwowanych wahań dynamiki, również średnie tempo wzrostu wykazało dużą rozpiętość procentową. Dodatnie średnie tempo wzrostu wykazały tylko dwie spośród badanych spółek: Budimex Group i Strabad Group. Pozostałe trzy spółki wykazały ujemne średnie tempo wzrostu w przedziale od $-14,8 \%$ do $-15 \%$.

W badanych spółkach marża netto wykazała duże zróżnicowanie. Przedział wielkości wynosił od 39,70\% do -11,18\%. Wśród badanych spółek w okresie sześciu lat trzy spółki utrzymały wielkość dodatnią marży. Średnia branżowa marża netto w badanych latach oscylowała w przedziale od $6,53 \%$ do $-15,92 \%$. Należy przy tym zaznaczyć, że budownictwo jest tą branżą, która odnotowuje z reguły niższe marże niż pozostałe sektory gospodarki.

dalszej kolejności badań poddano analizie marżę netto, inaczej - rentowność sprzedaży obrazującą relację zysku netto do przychodów ze sprzedaży. Wyniki analizy zostały przedstawione w tabeli 4 .

Tabela 4. Marża netto wybranych spółek branży budowlanej za lata 2014-2019 (w \%)

\begin{tabular}{|l|r|r|r|r|r|r|}
\hline \multicolumn{1}{|c|}{ Wyszczególnienie } & $\mathbf{2 0 1 4}$ & $\mathbf{2 0 1 5}$ & $\mathbf{2 0 1 6}$ & $\mathbf{2 0 1 7}$ & $\mathbf{2 0 1 8}$ & $\mathbf{2 0 1 9}$ \\
\hline Budimex Group & 3,92 & 4,61 & 7,37 & 7,30 & 4,14 & 3,02 \\
\hline Strabag Group & 4,74 & 4,64 & 6,74 & 1,00 & 0,95 & 3,61 \\
\hline Polimex Mostostal Group & $-7,29$ & 2,71 & $-2,28$ & $-5,70$ & 0,99 & 3,19 \\
\hline Warbud S.A. & 4,61 & 3,23 & 3,78 & 2,90 & 0,99 & 2,27 \\
\hline PBG Group & $-5,28$ & $-11,18$ & 39,70 & $-5,00$ & $-3,70$ & bd \\
\hline Średnia dla branży & 2,36 & 3,33 & 6,53 & 1,50 & 0,84 & $-15,92$ \\
\hline
\end{tabular}

Źródło: Opracowanie własne na podstawie: Deloitte (2019)

Kolejną wielkością poddaną analizie była marża operacyjna będąca miarą tego, jaka proporcja zysków ze sprzedaży pozostaje w spółce po zapłaceniu kosztów zmiennych produkcji. Zgodnie z teorią analizy fundamentalnej wymagany jest wysoki poziom marży operacyjnej firmy, aby była ona w stanie spłacać koszty stałe swojej działalności.

Wielkości marży operacyjnej badanych spółek przedstawiona została w tabeli 5.

Tabela 5. Marża operacyjna wybranych spółek branży budowlanej za lata 2014-2019 (w \%)

\begin{tabular}{|l|r|r|r|r|r|r|}
\hline \multicolumn{1}{|c|}{ Wyszczególnienie } & $\mathbf{2 0 1 4}$ & $\mathbf{2 0 1 5}$ & $\mathbf{2 0 1 6}$ & $\mathbf{2 0 1 7}$ & $\mathbf{2 0 1 8}$ & $\mathbf{2 0 1 9}$ \\
\hline Budimex Group & 8,74 & 9,60 & 13,50 & 12,70 & 8,50 & 7,30 \\
\hline Strabag Group & 3,65 & 7,48 & 7,00 & 1,20 & $-1,80$ & $-0,70$ \\
\hline Polimex Mostostal Group & $-9,59$ & 6,00 & 1,20 & 6,90 & 5,00 & 6,80 \\
\hline Warbud S.A. & 12,96 & 9,59 & 11,30 & 10,40 & 7,30 & 10,10 \\
\hline PBG Group & 6,18 & 6,54 & 6,10 & 9,30 & 9,70 & bd \\
\hline Średnia dla branży & 6,66 & 8,46 & 8,31 & 7,20 & 3,50 & 3,8 \\
\hline
\end{tabular}

Źródło: Opracowanie własne na podstawie: Deloitte (2019)

Jak wynika z przedstawionych ustaleń, w badanych spółkach wystąpiła duża rozpiętość wielkości marży oscylująca w przedziale od 12,96\% do -9.59\%. Najwyższe wartości wskaźnika odnotowały spółki Budimex Group i Warbud S.A., co może świadczyć o ich 
silnej marce oraz umiejętności utrzymywania kosztów zmiennych na niskim poziomie. Zaznaczyć przy tym należy, że średnia branży w badanych latach dla tej marży kształtowała się między wielkościami od 8,46\% do 3,50\%.

Pod względem wyników działalności ocenie została poddana również stopa zadłużenia obrazująca ogólną strukturę finansowania aktywów badanych spółek. Zostało to przedstawione w tabeli 6 .

Tabela 6. Stopa zadłużenia wybranych spółek branży budowlanej za lata 2014-2019 (w \%)

\begin{tabular}{|l|l|l|l|l|l|l|}
\hline \multicolumn{1}{|c|}{ Wyszczególnienie } & $\mathbf{2 0 1 4}$ & $\mathbf{2 0 1 5}$ & $\mathbf{2 0 1 6}$ & $\mathbf{2 0 1 7}$ & $\mathbf{2 0 1 8}$ & $\mathbf{2 0 1 9}$ \\
\hline Budimex Group & 0,86 & 0,87 & 0,86 & 0,85 & 0,86 & 0,87 \\
\hline Strabag Group & 0,70 & 0,73 & 0,67 & 0,74 & 0,72 & 0,75 \\
\hline Polimex Mostostal Group & 0,84 & 0,80 & 0,81 & 0,72 & 0,64 & 0,58 \\
\hline Warbud S.A. & 0,80 & 0,82 & 0,82 & 0,83 & 0,87 & 0,83 \\
\hline PBG Group & 1,31 & 1,37 & 0,88 & 0,84 & 0,88 & 4,50 \\
\hline Średnia branży & 0,77 & 0,79 & 0,75 & 0,76 & 0,75 & 1,02 \\
\hline
\end{tabular}

Źródło: Opracowanie własne na podstawie: Deloitte (2019)

Jak wynika z przedstawionych obliczeń, w badanych spółkach stopa zadłużenia mieściła się w przedziale od 0,58 do 4,50. Natomiast średnia branżowa tego wskaźnika dla badanych lat wahała się od 0,75 do 1,02. Spośród badanych spółek najwyższy wskaźnik odnotowano w PBG Group, co może świadczyć o nadmiernym ryzyku kredytowym. Z kolei najniższe wskaźniki bardzo zbliżone do branżowych wykazała spółka Strabag Group, co może wskazywać na jej dużą samodzielność finansową.

\section{Podsumowanie}

Przeprowadzone rozważania pozwalają stwierdzić, że w ostatnich latach analizowane spółki branży budowlanej notowane na GPW wykazały dosyć duże wahania w dynamice analizowanych wskaźników.

Wyniki za 2019 r. odzwierciedlają dynamiczną sytuację i skutki problemów, z którymi budownictwo borykało się już w 2018 r. Przychody całkowite z działalności w badanych spółkach wykazały dosyć dużą dynamikę, za wyjątkiem Budimex Group, w której odnotowano stabilny wzrost.

Wynik ze sprzedaży również nie pokazał stabilnego trendu wzrostowego - tylko trzy z badanych spółek odnotowało wyniki dodatnie. Natomiast dla Polimex Mostostal Group i Stabad Group ustalono tendencje spadkowe, wykazujące przy tym wyniki ujemne. Najwyższy ostateczny wynik finansowy ustalono dla spółki Budimex Group i Strabad Group. Wielkości marży netto pokazały duże zróżnicowanie, wartości dodatnie utrzymały trzy z badanych spółek: Budimex Group, Strabad Group i Warbud S.A.

Z kolei najwyższe marże operacyjne odnotowały spółki: Budimex Group i Warbud S.A.,co może świadczyć o ich silnej marce oraz niskim poziomie kosztów zmiennych.

Stopa zadłużenia mieściła się w przedziale 0,58-4,50, przy czym najwyższy jej wskaźnik wykazała PBG Group, co może sygnalizować nadmierne ryzyko kredytowe tej spółki. Najniższe wskaźniki wskazujące na dużą samodzielność finansową ustalono w przypadku spółki Strabad Group. 
Podsumowując, należy zauważyć fakt, że branża budowlana ma problemy z nierentownymi kontraktami: umowy podpisywane były na kilka lat przed realizacją, wzrost inwestycji sprawiał, że rosły ceny usług, urządzeń i materiałów. Swój wkład w zaistniałą sytuację miały też rosnące płace i niedobór pracowników.

Przedstawioną sytuację nieco poprawił nowy mechanizm waloryzacji kontraktów wprowadzony w 2019 r., który dotyczył jednak tylko stosunkowo nowych przedsięwzięć. Innymi obciążeniami były: niska rentowność branży, zwłaszcza dużych przedsiębiorstw, niskie marże na kontraktach realizowanych dla państwowych inwestorów, około trzyletni okres od podpisania umowy do rozpoczęcia robót stwarzający ryzyko utraty rentowności.

Zatem można wnioskować, że dla branży budowlanej potrzebne są takie działania, jak: równomierne rozłożenie ryzyka w umowach, realna waloryzacja wieloletnich projektów, stabilne i przewidywalne planowanie i finansowanie inwestycji.

Należy zatem stwierdzić, że podejmowanie trafnych i szybkich decyzji gospodarczych wymaga stałego dopływu kompleksowych i rzetelnych informacji gospodarczych. Na ich podstawie podejmuje się zarówno decyzje strategiczne, jak i decyzje taktyczne oraz operacyjne, dotyczące bieżącej działalności przedsiębiorstwa, oraz likwidacji niepożądanych odchyleń od założonych wzorców (Nesterowicz, 2014).

Aby móc utrzymać się na rynku i osiągać dobre wyniki ekonomiczne, należy przede wszystkim analizować trendy z przeszłości, aby na ich podstawie przewidywać przyszłe wyniki i warunki funkcjonowania firmy, a także podejmować decyzje określające kierunki jej rozwoju.

\section{Literatura}

References

Blocher, D. (2018). Budimex - największa firma budowlana w Polsce w 2018 r. wg raportu Deloitte Wysokie obroty, niskie marże - czy branża budowlana stanie się ofiara własnego sukcesu?

Deloitte. (2019). Raporty Polskie Spótki Budowlane za lata 2014-2019. Pozyskano z: https://www2.deloitte.com/pl/pl.html

Kieszkowski, W. (2018). Usługi budowlane. W: D. Prokop (red.), Mechanizm podzielonej płatności (split payment). Warszawa: Woleters Kluwer.

Krasoń, M. (2021; 4 września 2021). Zrównoważony rozwój motorem wzrostu dla branży budowlanej. Pozyskano z: https://www2.deloitte.com/pl/pl/pages/press-releases/articles/zrownowazony-rozwoj-motorem-wzrostu-dla-branzy-budowlanej.html

MerXu. (wrzesień 2021). Bankructwa firm budowlanych w 2021. Rośnie zadłużenie i liczba upadłości w budownictwie. Murator Plus. Pozyskano z: https://www.muratorplus.pl/biznes/raporty-i-prognozy/przybywa-bankructw-firm-budowlanych-aa-rTPY-9Zct-K2qb.html

Nesterowicz, R. (2014). Sprawozdawczość finansowa i jej rola w ocenie wyników działalności przedsiębiorstw. Nierówności społeczne a wzrost gospodarczy, 39, 320-329.

Nykiel, W., Sęk, M. (2018). Opodatkowanie konsumpcji. W: W. Nykiel (red.), Prawo podatkowe w Polsce. Podręcznik akademicki. Warszawa: Difin.

Skowronek-Mielczarek, A,. Leszczyński, Z. (2008). Analiza działalności i rozwoju przedsiębiorstwa. Warszawa: PWE.

Timofiejuk, I. (1973). Stopa wzrostu gospodarczego. Metody liczenia. Warszawa: PWE.

Zabrowarny, S. (red.). (2004). Ekonomia. Wyższa Szkoła Administracji i Zarządzania w Przemyślu, nr 77.

Renata Nesterowicz, dr nauk ekonomicznych, adiunkt dydaktyczny Uniwersytetu Rzeszowskiego, 
Kolegium Nauk Społecznych, Instytutu Ekonomii i Finansów w Katedrze Finansów i Rachunkowości. Autorka licznych publikacji z zakresu finansów i rachunkowości. Jej zainteresowania naukowe to ocena wyników i dokonań małych i średnich przedsiębiorstw w Polsce.

Renata Nesterowicz, PhD in Economics, assistant professor at the University of Rzeszów, College of Social Sciences, Institute of Economics and Finance at the Department of Finance and Accounting. Author of numerous publications in the field of finance and accounting. Research interests include the evaluation of the results and achievements of small and medium-sized enterprises in Poland.

ORCID: https://orcid.org/0000-0002-0254-9633

\title{
Adres/Address:
}

\author{
Uniwersytet Rzeszowski \\ Instytut Ekonomii i Finansów \\ Katedra Finansów i Rachunkowości \\ ul. Ćwiklińskiej 2a, p. 201 \\ 35-959 Rzeszów, Poland \\ e-mail: rbnester@onet.eu
}

Joanna Nakonieczny, dr nauk ekonomicznych, adiunkt badawczo-dydaktyczny Politechniki Rzeszowskiej, Wydziału Zarządzania, Zakładu Finansów, Bankowości i Rachunkowości. Wieloletni specjalista ds. rachunkowości finansowej. Członek Rady Nadzorczej spółki kapitałowej. Główny obszar badań jej zainteresowań obejmuje zagadnienia z zakresu rachunkowości finansowo-podatkowej, rachunkowości zarządczej i efektywności kapitału intelektualnego.

Joanna Nakonieczny, PhD in Economics, research and teaching assistant professor at Rzeszów University of Technology, Faculty of Management, Department of Finance, Banking and Accounting. Long-term specialist in financial accounting. Member of the Supervisory Board of a capital company. The main area of research covers issues in the field of financial and tax accounting, management accounting and the effectiveness of intellectual capital.

ORCID: https://orcid.org/0000-0002-5069-2514

\section{Adres/Address:}

Politechnika Rzeszowska

Wydział Zarządzania

Zakład Finansów, Bankowości i Rachunkowości

ul. Akademicka 2, Arcus, p. 320

35-084 Rzeszów, Poland

e-mail: j.nakonieczny@prz.edu.pl 